\title{
PENGOLAHAN DAN ANALISIS USAHA TANAMAN JAHE MENJADI PRODUK JAHE INSTAN DI PANTI ASUHAN AL-IKHLAS NGENTAK PELEM RT.13 BATURETNO BANGUNTAPAN BANTUL
}

\author{
Nurcahyani Dewi Retnowati ${ }^{1}$, Daru Retnowati ${ }^{2}$ \\ Program Studi Teknik Informatika Sekolah Tinggi Teknologi Adisutjipto ${ }^{1}$ \\ Jl. Majapahit Blok R Adisucipto Yogyakarta, \\ Fakultas Pertanian Universitas Pembangunan Nasional "Veteran" Yogyakarta \\ Jl. Ringroad Lingkar Utara Condong Catur Yogyakarta \\ Email : ndewiret@gmail.com ${ }^{1}$, daru.retnowati@gmail.com ${ }^{2}$
}

\begin{abstract}
Ginger plants are widely cultivated in Indonesia and can be used for health. One of the ginger products is instant ginger. The process of making instant ginger can be easily done by everyone, especially the children of the orphanage. The aim of community service is that children of Orphanage are expected to make their own instant ginger, sell, and do business analysis calculations so that the children of the Orphanage become more independent. The training process for making instant ginger and business analysis was carried out at the Al-Ikhlas Orphanage Ngentak Pelem RT.13 Baturetno Banguntapan Bantul Yogyakarta. The method carried out in the implementation of this training was by counseling and practicing directly the making of instant ginger and calculation of business analysis. There are three types of activities, namely an explanation of ginger plants and their properties, making instant ginger products, and teaching business analysis calculations and a little about product marketing. The output target to be achieved in this community service is that the partners are able to make instant ginger and business analysis.
\end{abstract}

Keywords: Medicinal Plants, Instant Ginger, Business Analysis

Abstrak

Tanaman jahe banyak dibudidayakan di Indonesia dan dapat dimanfaatkan untuk kesehatan. Salah satu produk hasil olahan jahe berupa jahe instan. Proses pembuatan jahe instan yang mudah dapat dilakukan oleh semua orang, khususnya anak-anak Panti Asuhan. Tujuan dari pengabdian masyarakat ini diharapkan anak-anak Panti Asuhan dapat membuat jahe instan sendiri, menjual, dan melakukan perhitungan analisis usaha sehingga anak-anak Panti Asuhan menjadi lebih mandiri. Proses pelatihan pembuatan jahe instan dan analisis usaha dilaksanakan di Panti Asuhan Al-Ikhlas Ngentak Pelem RT.13 Baturetno Banguntapan Bantul Yogyakarta. Metode yang dilakukan dalam pelaksanaan pelatihan ini adalah dengan penyuluhan dan praktek secara langsung pembuatan jahe instan dan perhitungan analisis usaha. Tahapan kegiatan ada 3 macam yaitu penjelasan tentang tanaman jahe dan khasiatnya, pembuatan produk jahe instan, dan mengajarkan perhitungan analisis usaha dan sedikit tentang pemasaran produk. Target luaran yang ingin dicapai pada pengabdian masyarakat ini yaitu mitra mampu membuat jahe instan dan analisis usaha.

Kata Kunci: Tanaman Obat, Jahe Instan, Analisis Usaha 


\section{Latar Belakang}

Terdapat 31 jenis tanaman obat di Indonesia yang dapat digunakan sebagai bahan baku industri jamu maupun industri bukan jamu. Tanaman obat tersebut banyak dimanfaatkan sebagai bahan jamu gendong, obat herbal, kosmetik dan spa, serta bahan industri makanan dan minuman [1]. Salah satu tanaman obat yang dapat dibudidayakan dan bermanfaat adalah jahe. Peluang tanaman jehe untuk dikembangkan di Indonesia sangat besar, hal ini dikarenakan budidaya tanaman ini sangat cocok dengan iklim, kondisi tanah dan letak geografis. Jahe banyak dimanfaatkan sebagai bahan campuran makanan, minuman, kosmetika dan bahan baku dalam kegiatan industri [2]. Produk olahan jahe dapat berupa jahe instan yang pembuatannya cukup mudah. Dalam proses pembuatan jahe instan juga perlu diperhatikan faktor kebersihan dalam proses produksi dan pemilihan jahe berkualitas bagus sehingga dapat menghasilkan produk jamu jahe instan yang berkualitas [3]. Manfaat ekstrak jahe bagi kesehatan antara lain sebagai untuk mengobati sakit kepala, batuk, masuk angin, untuk gangguan pada saluran pencernaan, antimual dan mabuk perjalanan [4]. Jahe kaya akan kandungan kalori dan fosfor [5]. Sifat khas jahe disebabkan adanya minyak atsiri dan oleoresin jahe. Aroma harum jahe disebabkan oleh minyak atsiri, sedangkan oleoresinnya menyebabkan rasa pedas [6]. Tidak semua orang mengetahui manfaat jahe bagi kesehatan dan bagaimana cara mengolahnya. Sebelum melaksanakan kegiatan pengabdian kepada masyarakat, dilakukan kegiatan survei dan wawancara terlebih dahulu. Survei tersebut memiliki tujuan untuk mengetahui bagaimana permasalahan yang dihadapi mitra atau peserta pengabdian kepada masyarakat dan kesiapan mitra menerima teknologi yang akan diterapkan [7]. Hasil survey dan wawancara dengan mitra dalam hal ini anak-anak Panti Asuhan Al-Ikhlas didapatkan suatu masalah antara lain kurangnya minat anak-anak panti asuhan dalam memanfaatkan tanaman herbal, khususnya jahe, selain untuk digunakan sebagai bumbu dapur, sehingga diselesaikan dengan mengadakan pelatihan pengolahan tanaman jahe (rimpang) menjadi produk jadi jahe instan, serta ketidaktahuan dalam membuat analisis usaha, hal ini diselesaikan dengan mengadakan pendampingan perhitungan analisis usaha produk jahe instan. Kegiatan pengabdian pada masyarakat dititikberatkan dalam bentuk pelatihan pembuatan dan pengolahan tanaman jahe menjadi produk jahe instan serta didampingi pula dalam membuat analisis usaha. Diharapkan dengan adanya penyuluhan dan pelatihan tersebut, mitra atau peserta pengabdian kepada masyarakat dapat membuat sendiri produk jahe instan dalam skala besar dan memasarkannya sehingga mendapatkan laba atau keuntungan dari hasil penjualan serta dapat melakukan analisis usaha.

\section{Metodologi Pelaksanaan} berikut:

Metode pengabdian masyarakat yang diberikan kepada mitra adalah sebagai

a. penyuluhan berupa penjelasan mengenai tanaman obat dan manfaat jahe bagi kesehatan

b. pelatihan pembuatan jahe instan, mitra atau peserta pengabdian juga melakukan praktek langsung pembuatan jahe instan.

c. pelatihan analisis usaha

\section{Hasil dan Pembahasan}

Kegiatan pengabdian kepada masyarakat dengan mitra atau peserta pengabdian anak-anak Panti Asuhan Al-Ikhlas berjumlah 14 orang anak dilaksanakan di Panti Asuhan Al-Ikhlas Ngentak Pelem RT13 Baturetno Banguntapan Bantul Yogyakarta 
pada hari Minggu tanggal 22 April 2018, dengan tiga macam tahapan kegiatan sebagai berikut:

a. penjelasan tentang tanaman jahe dan khasiatnya

b. pembuatan produk jahe instan

c. mengajarkan perhitungan analisis usaha dan sedikit tentang pemasaran produk.

Kegiatan pengabdian kepada masyarakat diawali dengan penyuluhan penjelasan tanaman obat, tanaman jahe dan manfaat jahe bagi kesehatan selama 15 menit, dilanjutkan dengan pelatihan pembuatan jahe instan yang juga dilakukan praktek langsung oleh peserta pengabdian selama 3 jam 15 menit, kemudian diajarkan tentang analisis usaha produk jahe instan dimana para peserta juga melakukan praktek perhitungan analisis usaha selama 45 menit, dan penjelasan singkat tentang pemasaran selama 15 menit.

Peralatan dan perlengkapan yang dibutuhkan selama pengabdian disediakan oleh pelaksana pengabdian. Peralatan dan perlengkapan tersebut adalah peralatan dan perlengkapan yang mudah didapatkan dan disesuaikan dengan kondisi mitra. Pelaksana pengabdian juga memberikan modul pelatihan yang dapat dipelajari oleh mitra. Cara atau proses pembuatan produk jahe instan juga terbilang cukup mudah sehingga peserta pengabdian dapat melakukannya dengan baik. Langkah awal pembuatan produk jahe isntan, tanaman jahe dibersihkan terlebih dahulu dari tanah yang menempel kemudian mencucinya dengan air mengalir. Pada saat proses pembersihan jahe dari tanah dan proses pencucian, pelaksana pengabdian juga menjelaskan pentingnya kedua proses tersebut pada kualitas produk jahe instan yang akan dibuat. Proses selanjutnya adalah dengan memarut jahe yang sudah bersih dengan alat parutan.

Pelaksana pengabdian kepada masyarakat memberikan pengarahan dan pelatihan kepada mitra atau peserta pengabdian kepada masyarakat seperti pada Gambar 1. Praktek pembuatan jahe instan yang dilakukan oleh mitra atau peserta pengabdian kepada masyarakat dapat dilihat pada Gambar 2a dan Gambar 2b. Produk yang dihasilkan dari kegiatan pengabdian kepada masyarakat berupa jahe instan yang telah dikemas dalam plastik dan siap untuk dijual dapat dilihat pada Gambar 3.

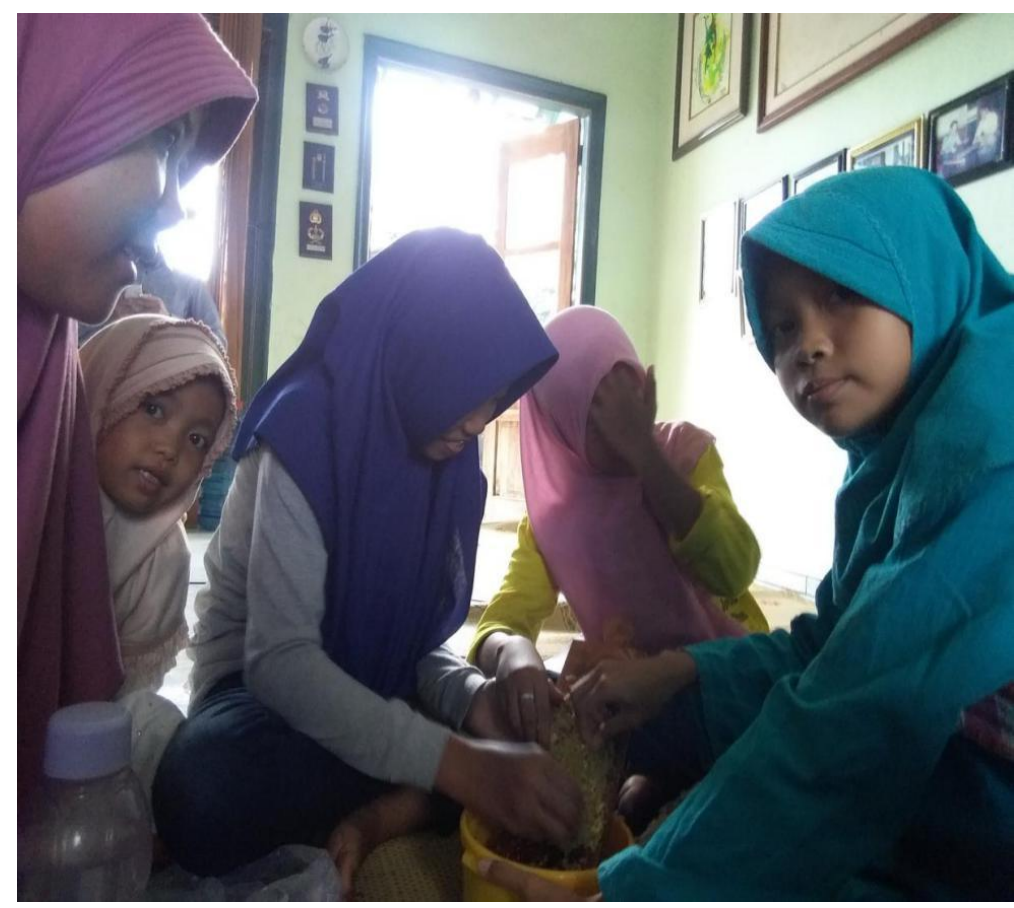

Gambar 1. Pelaksana Pengabdian Memberikan Pengarahan Kepada Mitra Atau Peserta Pengabdian Kepada Masyarakat 


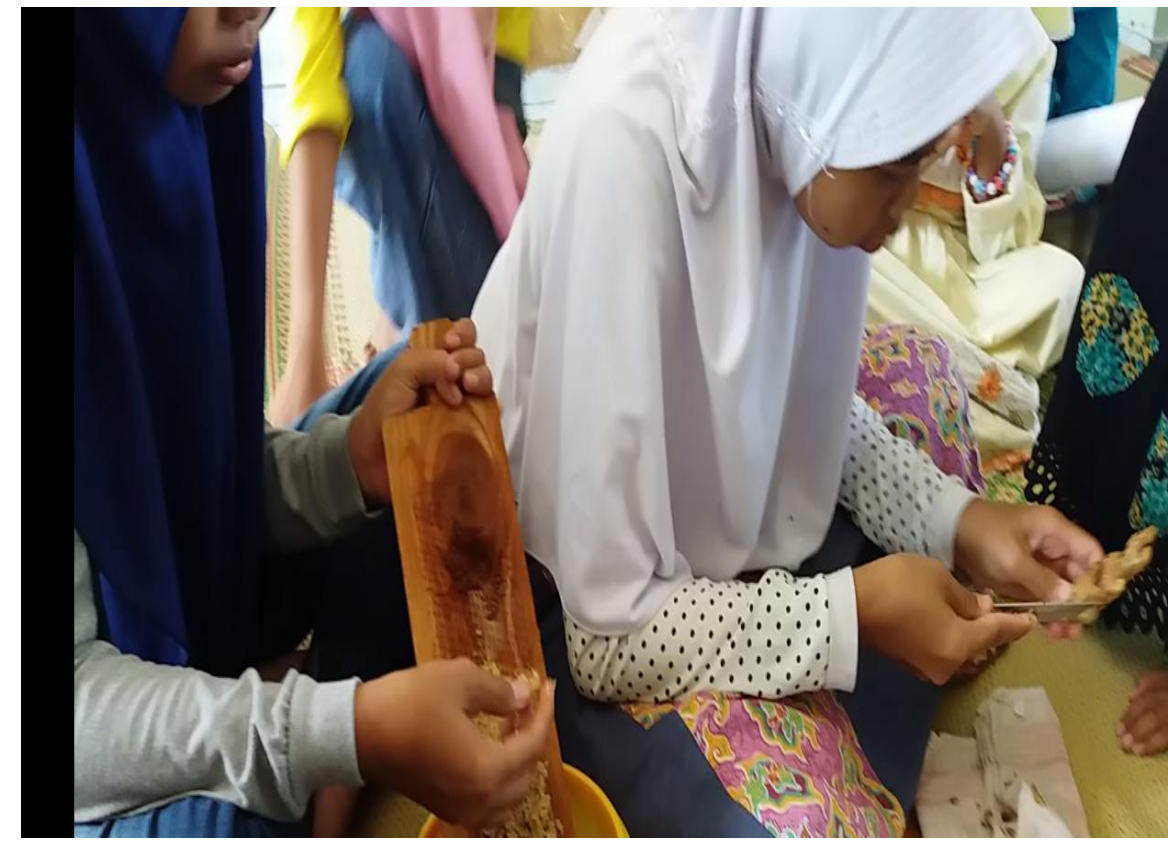

Gambar 2a. Mitra atau Peserta Pengabdian Praktek Membuat Jahe Instan

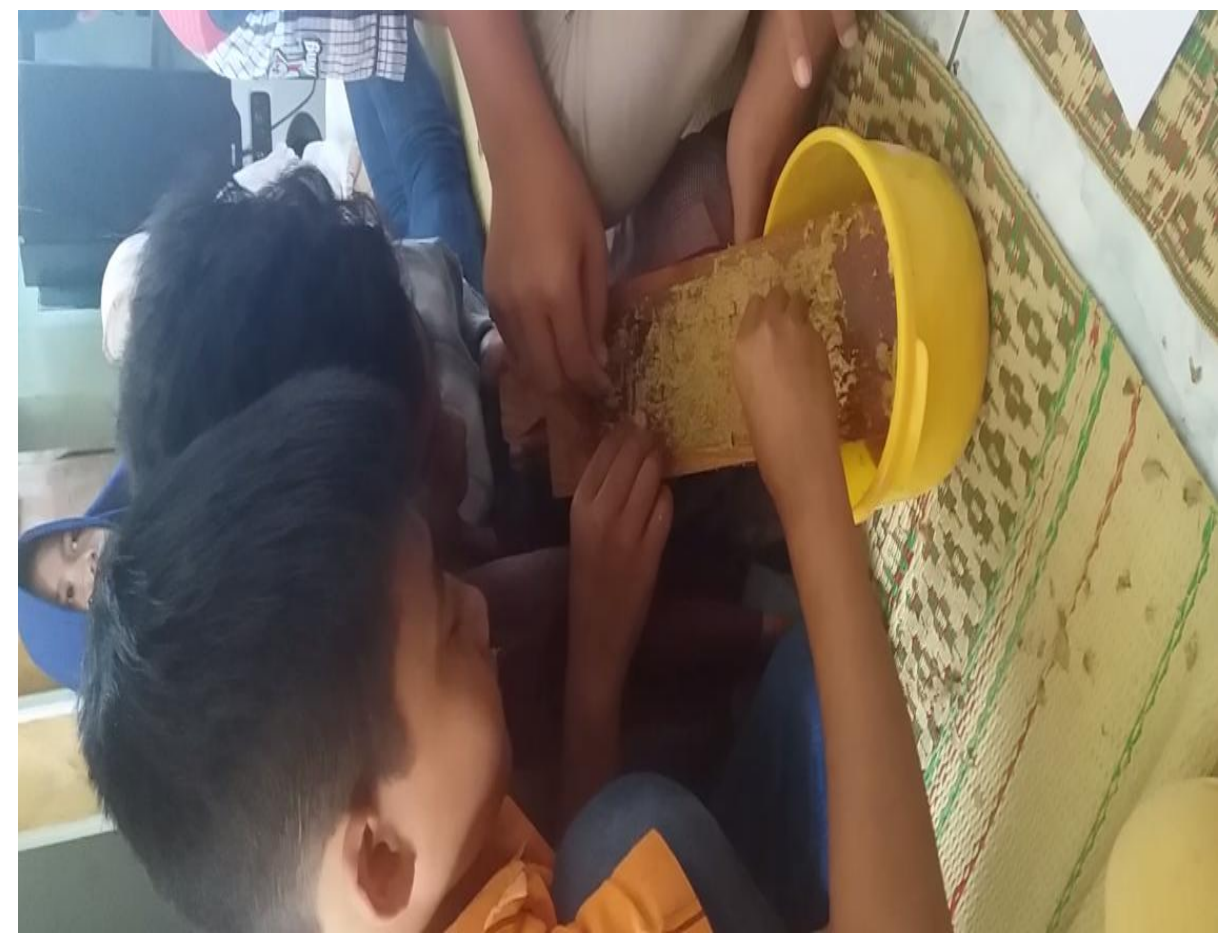

Gambar 2b. Mitra atau Peserta Pengabdian Praktek Membuat Jahe Instan

Pada saat memarut jahe, pelaksana pengabdian juga memberikan penjelasan tentang kebersihan tangan saat memarut, oleh karena itu peserta pengabdian yang akan memarut jahe harus terlebih dahulu mencuci tangannya dengan sabun dan air bersih. Dalam setiap tahapan kegiatan, pelaksana pengabdian tidak hanya memberikan pelatihan, namun juga memberikan pengarahan-pengarahan kepada peserta pengabdian. 


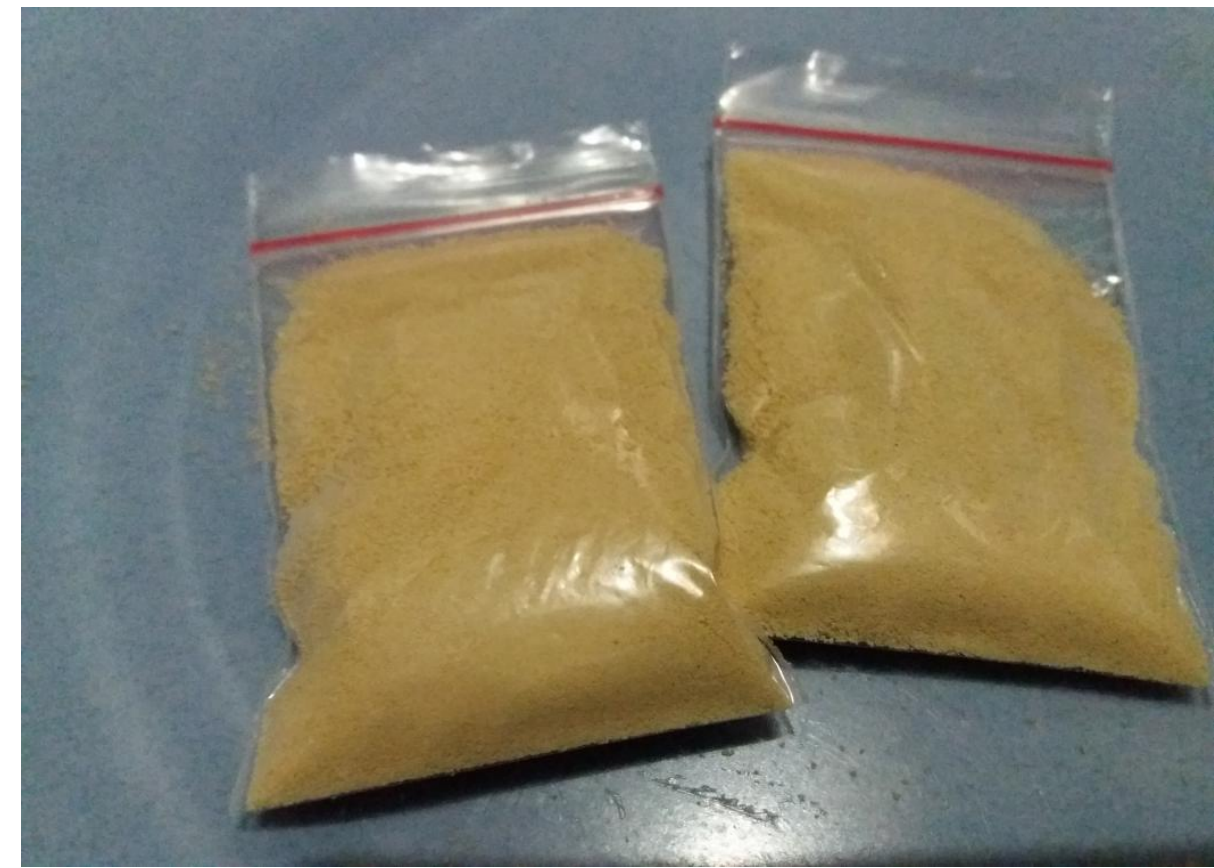

Gambar 3. Produk Jahe Instan Hasil Kegiatan Pengabdian yang Dibuat Oleh Mitra Atau Peserta Pengabdian Kepada Masyarakat

Setelah pelaksanaan pelatihan dan praktek pembuatan jahe instan, pelaksana pengabdian melakukan evaluasi terhadap mitra atau peserta pengabdian. Hasil dari evaluasi tersebut didapatkan bahwa 2 dari 14 orang peserta pengabdian masih belum bisa melakukan pengolahan jahe instan, hal ini dikarenakan peserta pengabdian tersebut masih belum terbiasa menggunakan peralatan yang digunakan. Setelah pelatihan perhitungan analisis usaha, juga dilakukan evaluasi terhadap mitra dan didapatkan hasil semua mitra atau peserta pengabdian sudah dapat melakukan perhitungan analisis usaha. Pada kegiatan pengabdian kepada masyarakat tersebut juga dijelaskan sedikit tentang bagaimana cara pengemasan yang baik dan memasarkan produk jahe instan dengan cara yang mudah.

\section{Kesimpulan}

Kegiatan pengabdian kepada masyarakat berupa penyuluhan dan pelatihan yang diberikan kepada mitra atau peserta pengabdian anak-anak Panti Asuhan Al-Ikhlas mendapatkan hasil sebagai berikut:

1. Anak-anak panti asuhan dapat memahami penjelasan tentang tanaman jahe dan mafaatnya bagi kesehatan.

2. Hasil evaluasi pelatihan produk jahe instan didapatkan bahwa 2 dari 14 orang peserta pengabdian masih belum terbiasa menggunakan peralatan yang digunakan.

3. Produk jahe instan yang telah dibuat sesuai dengan langkah-langkah yang diajarkan dalam modul pengabdian.

4. Hasil evaluasi pelatihan perhitungan analisis usaha didapatkan bahwa semua peserta pengabdian dapat melakukan perhitungan analisis usaha

\section{Daftar Pustaka}

[1] Pribadi, E. R. (2015). Pasokan dan permintaan tanaman obat Indonesia serta arah penelitian dan pengembangannya. Perspektif, 8(1), 52-64. 
[2] Astriani, D., Dinarto, W., \& Mildaryani, W. (2013). Penerapan Agroteknologi Tanaman Jahe dan Pengolahan Rimpangnya sebagai upaya Peningkatan Kesejahteraan Petani di Dusun Sorogaten dan Kaliberot. Jurnal Agrisains, 4(7).

[3] Muttaqin, H., Cahyadin, M., \& Widiyanti, E. (2015). Pemberdayaan Usaha Jamu Jahe Instan Di Kota Surakarta Dan Kabupaten Sukoharjo Melalui Teknologi Pengolahan Jahe. INOTEKS, 19(2).

[4] Afifah, N., Sholichah, E., \& WA, C. E. (2011). Rancangan Proses Produksi Minuman Instan Skala Industri Kecil dari Empon-Empon. Prosiding SNaPP: Sains, Teknologi, 2(1), 393-400.

[5] Chy Ana. 10 Manfaat Tanaman Jahe Bagi Kesehatan. Online: https://manfaat.co.id/manfaat-tanaman-jahe diakses pada tanggal 7 April 2019.

[6] Koswara, S. (2006). Jahe, rimpang dengan sejuta khasiat. Jakarta: Pustaka Sinar Harapan.

[7] Novia, L. (2014). IbM Kelompok Masyarakat Osing Dalam Pemanfaatan Tumbuhan Obat Tradisional Suku Osing Banyuwangi. 